医器学 Vol. 54, Suppl. (1984)

内られている。通常の流入方式では流体はほと んど予施回無しに流入するため， $\beta_{1}$ は一般に $10^{\circ} \sim 20^{\circ}$ 程度である. 一方今回試作したポン プでは, 羽根車流入直前汇回転円筒内を流体が 通過してくるため, 流体にかなりの予施回が与 えられ,これが流量特性, 効率などに影響する ことが考えられる。そこで本ポンプにおける適 切な羽根入口角度に関する知見を得るため, 通 常の流入方式ポンプとの比較を， $\beta_{1}$ と効率との 観点から検討した。図 5 は通常の流入方式渦巻 ポンプと今回試作したポンプのクーQ特性を比 較したもので，図上部は低い $\beta_{1}\left(10^{\circ}\right)$ ，下部は 高い $\beta_{1}\left(90^{\circ}\right)$ に扔汀るものである。この図よ りシールレスポンプの効率は, 通常の流入方式 ポンプに比べ低い $\beta_{1}$ で減少し，逆に高い $\beta_{1}$ で 增加していることがわかる。これは前述した予 施回の影響によるものと考えられ，効率特性の 向上には $\beta_{1}$ を一般の渦巻ポンプよりもかなり 大きくする必要があることが確認された.

図6はポンプ特性の最も良好であった $\beta_{1}=$ $90^{\circ}, \beta_{2}=50^{\circ}$ の羽根の $\mathrm{H}-\mathrm{Q}$ 特性扩よびク $-\mathrm{Q}$ 特性を回転数をパラメータとして示したもので ある. $3000 \mathrm{rpm}$ では無負荷時最大流量 $20 \mathrm{l} /$ $\mathrm{min}$, 負荷圧 $200 \mathrm{mmHg}$ で $14 \mathrm{l} / \mathrm{min}$ 程度の流 量で得られている。最大効率は約 $45 \%$ で，この 時の流量は回転数の増加と共に $4 \mathrm{l} / \mathrm{min}$ から $9 \mathrm{l} / \mathrm{min}$ 一と増加している.

以上示したように今回試作したジールスボ ンプは，血液灌流用として十分なボンプ特性を 有して㧍り，さらに軸受・軸封機構が全くなく 簡易構造であるため, ポンプヘッド部のディス ポーザブル化が極めて容易と考えられる。今 後, 血液ポンプとしての最適羽根形状を, 溶血 量, ポンプ内流れの安定性などの面から検討し ていく予定である.

なおポンプ駆動用ブラシレスサーボモータを製作 するにあたり，東栄電気桻の技術協力を得た。ここ に謝意を表したい.

\title{
14. 補助人工心蔵用ポリウレタン製人工弁の試作
}

\section{1. 目的}

現在, われわれ補助人工心臓用人工弁とし て Bjork-Shiley 傾斜型ディスク弁（以下B-S 弁）を使用しているが，補助人工心臓專用であ り，また同じ材質のポリウレタンで人工弁が作 成できれば, ポンプ特性の改善, 抗血栓性およ びコストの点で有利と考えられる. 今回, この 目的に従い，ポリウレタン製三尖弁を試作し， その水力学的特性を評価したので報告する.

\section{2. 基本構想}

補助人工心臟用人工弁として考慮す心゙き点

* 国立循環器病センター研究所
野田裕幸* 梅津光生* 中谷武嗣* 妙中義之* 田中 隆*岩田博夫* 松由武久*高野久輝* 阿久津哲造*

は，1）水力学的特性，2）耐久性，3）占有体 積，4）抗血栓性, 5）カルシウム等の沈着等が あげられる. 今回, 試作研究の第 1 段階とし て, B-S 弁と同等以上の水力学的特性を有し, 3 カ月のポンプ駆動に耐えることを目標とし, その他の点については今後の課題とすることと して設計, 試作觉行った。

\section{3. デザイン，材料およひ製作}

形状は三尖弁とし，材料はわれわれが補助人 工心臓の作製に用いている東洋紡績社製セグメ ント化ポリウレタンTMシリーズである，製作 は同形球の合体を基本とする三尖弁モールドを 使用して, Dipping 法により一体成形を行っ 


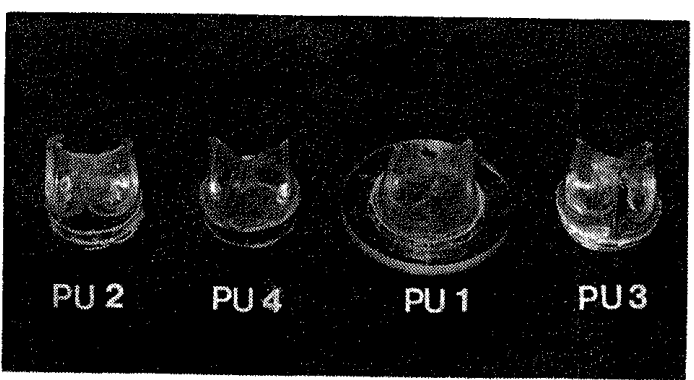

Fig. 1

た.モールドの直径は $23 \mathrm{~mm}$ である。

ステント部は可動性を有する方が閉鎖時に弁 葉部にかかる圧力を吸収し得，耐久性の点で有 利と考え, 弁葉の肉厚を $0.3 \mathrm{~mm}$ に固定した 上で, ステントの可動性の異なる 3 種の弁を作 製した. Fig. 1 に作製した各弁を示す.

PU-1, PU-2 はステント中心にステンレス ワイヤーを有する弁で，可動性が良好である。 PU-2 はステントを軟質塩ビにて作製したもの で，評価試験に用いた $15^{\circ} \mathrm{C}$ 水道水中では塩ビ が硬化しステントはほとんど可動性を失う。 PU-3 はステント全体をステンレスワイヤーに て固定したもので，ステントの可動性は全くな ᄂ.

\section{4. 評価方法}

試作したポリウレタン弁について，従来当研 究室で人工弁に対し行ってきた水力学的特性試 験を行った．比較対照として B-S 弁の他に代 表的三尖弁 の 1 つである Ionescu Shiley 牛 心のう膜弁（以下I-S弁）を用いた。なお $\mathrm{B}-\mathrm{S}$ 弁, I-S 弁共, 試験の弁径 $23 \mathrm{~mm}$ に相 当するサイズのものを使用した。また試験には 従来ど打り $15^{\circ} \mathrm{C}$ 水道水を用いた。

1 ）定常流抵抗試験； 2 基の高さの異なる才 ーバフロータンク間に，試験弁とニードル弁を 直列に置き，ニードル弁により通過流量を変化 させ，流量に対する弁前後の圧較差を計測し た.

2）定圧もれ試験； $100 \mathrm{~cm}$ 水柱の圧負荷に 対する弁閉鎖位に㧍けるもれ量を直接計測し た.

3) 拍動流試験 ; 直管型空気圧駆 動式 ポン プ, オーバフロータンク, コンプライアンスタ ンク等で構成される機械式循環シミュレータに

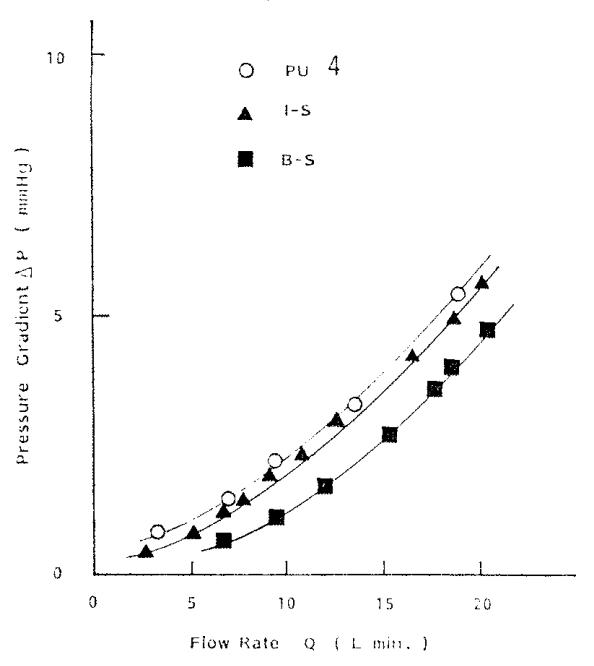

Fig. 2 Relationship between Flow \& Pressure Gradient (Steady Flow)
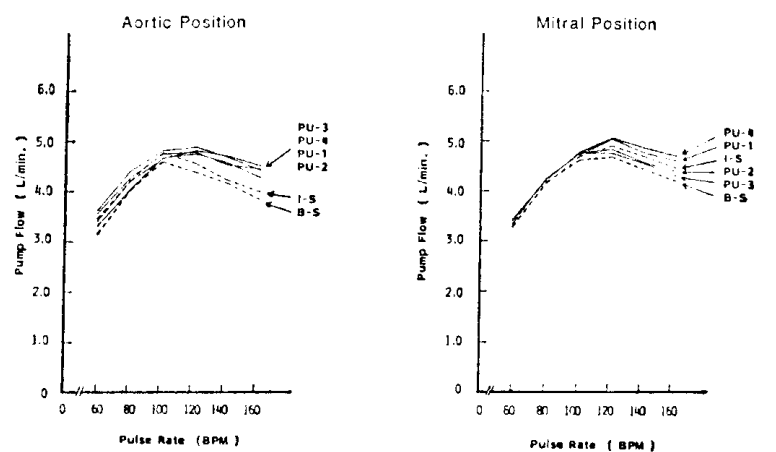

Fig. 3 Relationships between Pump Flow \& Pulse Rate

試験弁を装着し，流量，弁前後の圧較差算出弁 口面積と拍動数との関係を求めた。試験弁はポ ンプの大動脈弁位，僧帽弁位におのおの装着 し, 対側はB-S 弁 $25 \mathrm{~mm}$ に固定して 試験を 行った. ポンプの駆動条件は従来の市販の人工 弁を試験する際と同等とし，また，算出弁口面 積は Gorlin の式に基づいた。

\section{5. 試験結果}

1）定常流抵抗試験結果；Fig. 2 にステント に可動性を有する PU-4 および B-S 弁, I$\mathrm{S}$ 弁の試験結果を示す. PU-4 は B-S 弁より も圧較差は大きいが，ほぼ I-S 弁と同様の傾 向を示し，流量の増加に従って圧較差は単調増 加した。

2）もれ試験結果；PU-4 は $150 \mathrm{ml} / \mathrm{min} て ゙$ あり， B-S 弁の $320 \mathrm{ml} / \mathrm{min}, \quad \mathrm{I}-\mathrm{S}$ 弁の 50 
医器学 Vol. 54, Suppl. (1984)
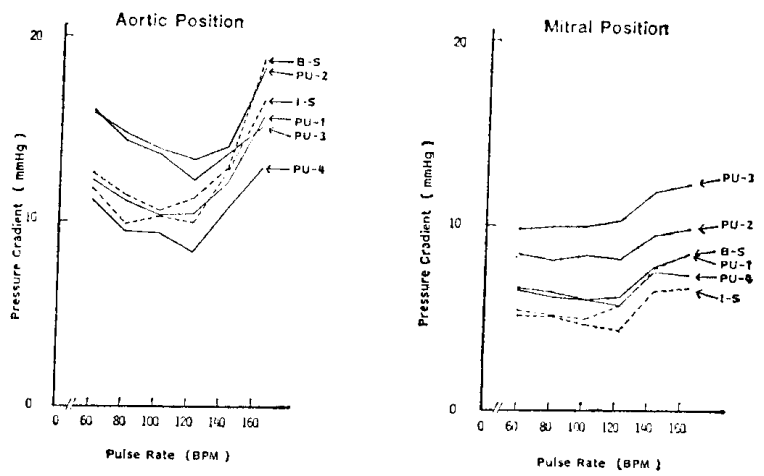

Fig. 4 Comparison of Pressure Gradient
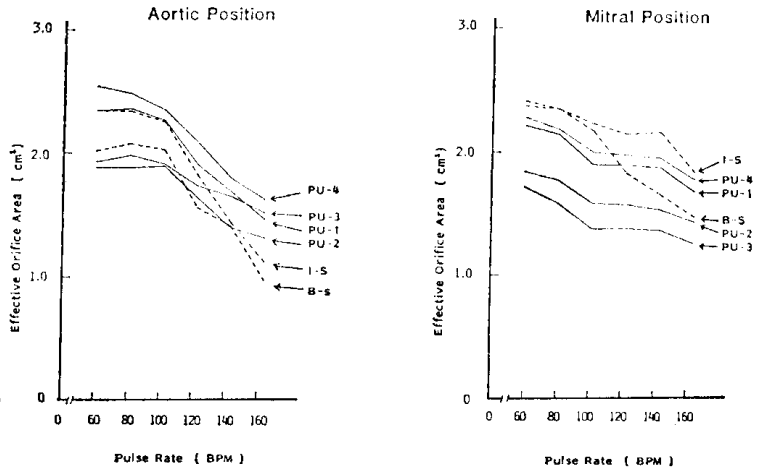

Fig. 5 Comparison of Calculated Effective Orifice Areas

$\mathrm{ml} / \mathrm{min}$ の中間の值を示し，もれ量としては問 題がなかった。

3）拍動流試験結果；流量と拍動数との関倸 を Fig. 3 に示す. 大動脈弁位において，拍動 数 $100 \mathrm{BPM}$ までは各弁間に差はないが，それ 以上の領域でポリウレタン弁は, 高值に流量を 維持できた。僧帽弁ではステントの可動性のあ る PU-1, PU-4 が, ステントの可動性にそし いPU-2, PU-3 に比し, 拍動数 100 BPM 以 上で流量が多かった.

弁前後の圧較差と拍動数の関係を Fig. 4 に 示す，大動脈弁位においては，全拍動域でステ ントの可動性のある PU-1， PU-4 が圧較差は 少なく，I-S 弁に匹敵する．僧帽弁位でも， すべてのポリウレタン弁は I-S 弁よりも圧較 差は大きいものの PU-1, PU-4 は, B-S 弁 とほぼ同様の傾向を示した。
算出弁口面積と拍動数の関係を Fig. 5 に示 す. 大動脈弁位では，ステントの可動性を有す る PU-1，PU-4 が，す心゙ての拍動域で I-S 弁よりも弁口面積が大きい，またステントの可 動性に乏しいPU-2, PU-3 \&，拍動数 100 BPM 以上の領域でよく弁口面積を維持し得 た，僧帽弁位では，ポリウレタン弁は $\mathrm{I}-\mathrm{S}$ 弁 に及ばないが，PU-1，PU-4 のステントの可 動性のあるものは拍動数が高、領域でも弁口面 積の減少が少なかった。

\section{6. 考 察}

今回試作したポリウレタン弁は，Fig. 3 亿示 すとおり流量特性が良好であり，特に高拍動域 においてもよく流量を維持できた。これは収 縮, 拡張の圧変化に対する弁葉の念答性の良さ に加え，閉鎖時のもれ量の少なさに起因すると 考える. また Fig. 4 に示すよらにポリウレタ ン弁は圧較差が大きい傾向にあるが，それも $\mathrm{B}-\mathrm{S}$ 弁々同程度のものであり，かつ補助人工 心臓という駆動圧を変化させ得る環境下では, 使用上，問題がないと考える。

耐久性を考慮し，ステントを可動性にした が，水力学的特性に㧍いても優れ，今後の方針 となった。

\section{7. 結 論}

補助人工心臟用としてポリウレタン製三尖弁 を試作した。 その水力学的特性は良好で, 特に 流量特性において優れ, 補助人工心臓用として 十分に使用可能であることが示された。またス テントの可動性の有無が水力学的特性にも大き く影響を与えることが判明した。 今後 in vitro に扔ける耐久性と共に, in vivo での評価も行 いつつ, 試作を続け, 補助人工心臟用ポリウレ タン弁の実用化をめざしたい.

\section{文献}

梅津光生他 : 新しい心臟代用弁の in-vitro 機能特 性, 人工藏器 $12(1) ; 146,1983$ 